\title{
Voidaanko peltoviljelyn valinnoilla edistää samanaikaisesti vesiensuojelua ja luonnon monimuotoisuutta?
}

\author{
Janne Helin $^{1)}$, Kari Hyytiäinen ${ }^{1)}$, Mikko Kuussaari ${ }^{2)}$ ja Eeva-Liisa Alanen ${ }^{2)}$ \\ ${ }^{1)}$ Maa- ja elintarviketalouden tutkimuskeskus Latokartanonkaari 900790 Helsinki, \\ etunimi.sukunimi@mtt.fi \\ ${ }^{2)}$ Suomen ympäristökeskus Mechelininkatu 34a,00251 Helsinki, etunimi.sukunimi@syke.fi
}

\section{TIIVISTELMÄ}

Vesistöjen ravinnekuormitus ja maatalousluonnon köyhtyminen ovat täpeltoviljelyn negatiivisia ympäristövaikutuksia. Monimuotoisuutta ja vesiensuojelua edistetään osaksi samoilla toimenpiteillä, esimerkiksi kesannoimalla. Ympäristö- ja maatalouspolitiikan kannalta on kiinnostavaa, kuinka suuria kustannussäästöjä on saavutettavissa, jos nämä toimenpiteet suunnitellaan alueellisesti koordinoidusti sekä monimuotoisuutta että vesiensuojelua silmälläpitäen. Tätä kysymystä voidaan tarkastella alueellisesti heterogeenisen pellonkäytönn optimointimallin avulla.

Tutkimuksessa haettiin kustannustehokkaita toimenpideyhdistelmiä monimuotoisuuden ja vesiensuojelun yhteistuotannolle valuma-aluetasolla. Esimerkkialueena oli Lepsämänjoen valuma-alue Vantaanjoen vesistössä. Mallissamme viljelijä tekee päätöksiä peltojen maankäytöstä (ohranviljelyn ja erilaiseten kesantojen välillä) sekä lannoituksen määrästä ohranviljelyaloilla. Malli sisältää kuvauksen erilaisten peltolohkojen ravinnekuormitusalttiudesta sekä asiantuntija-arvioihin perustuvan kuvauksen viljelypäätösten ja peltolohkojen ominaisuuksien vaikutuksesta peltoluonnon monimuotoisuuteen. Aineisto alueen maankäytöstä ja peltojen ominaisuuksista tallennettiin paikkatietojärjestelmään. Tämä tieto yhdistettiin toimenpiteiden vaikuttavuuden kanssa optimointimallissa.

Tulostemme mukaan koordinoitu monimuotoisuuden ja vesiensuojelun suunnittelu tuottaa kustannussäästöjä verrattaessa tilanteeseen, jossa toimenpiteet suunnitellaan toisistaan riippumatta. Lannoituksen vähentäminen on tehokkain tapa aloittaa vesiensuojelu. Korkeampiin vesiensuojelullisiin tavoitteisiin pyrittäessä on kustannustehokasta yhdistää lannoituksen vähentämistä ohra-alalla viherkesantoalan kasvattamisee huuhtoutumisherkimmillä peltolohkoilla. Monimuotoisuuden edistämisessä tehokkain keino on niittykasviseoksella perustettu kesanto. Näitä kesantoja perustettiin tulosten mukaan ensin jyrkkärinteisimmille, metsään rajoittuville ja etelään avautuville peltolohkoille. Sekä vesiensuojelua että monimuotoisuutta edistävät taloudellisesti tehokkaat toimenpideyhdistelmät koostuivat sekä lannoituksen vähentämisestä että niittykasvialan lisäämisestä ja kohdentamisesta. Koordinoidulla monimuotoisuuden ja vesiensuojelun suunnittelulla saavutettavat kustannussäästöt ovat ehdollisia laskentamallin oletuksille, valuma-alueen ominaisuuksille, vaihtoehtoisten toimenpiteiden määrille ja niiden vaikuttavuudelle sekä myös sille missä suhteessa yhteiskunta arvostaa vesien- ja monimuotoisuuden suojelua.

Asiasanat: biodiversiteetti, fosfori, optimointi, monivaikutteisuus, paikkatieto, ravinnekuormitus, typpi 


\section{JOHDANTO}

EU-27 alueella lähes puolet maa-alasta on viljelyksessä. Tehostuneen peltoviljelyn kaksi keskeistä negatiivista ulkoisvaikutusta ovat kasvi- ja eläinlajiston köyhtyminen ja ravinteiden huuhtoutuminen vesistöihin. Euroopan ympäristökeskuksen (EEA) mukaan $76 \%$ maatalousympäristön luontotyypeistä on epäsuotuisessa tilassa. EU:n monimuotoisuuden suojelun toimintasuunnitelmassa onkin tavoitteena, että jäsenvaltiot ottaisivat monimuotoisuuden kriteeriksi maatalouden, maaseudun kehittämisen ja metsäpolitiikan suunnittelussa. Nitraatti- ja vesipolitiikan puitedirektiivit ja niihin liittyvät kansalliset toimenpideohjelmat taas pyrkivät vähentämään maatalouden vesistökuormitusta.

Monimuotoisuutta ja vesiensuojelua edistetään osaksi samoilla toimenpiteillä, esim. kesannoimalla. Ympäristö- ja maatalouspolitiikan kannalta kiinnostava kysymys onkin, kuinka suuria kustannussäästöjä on saavutettavissa, jos näiden toimenpiteiden sijoittaminen valuma-alueen eri tilojen ja peltolohkojen kesken toteutetaan koordinoidusti sekä monimuotoisuutta että vesiensuojelua silmälläpitäen. Tähän kysymykseen haetaan tässä tutkimuksessa vastausta alueellisesti heterogeenisen optimointimallin avulla.

Tutkimuksessa haettiin kustannustehokkaita toimenpideyhdistelmiä monimuotoisuuden ja vesiensuojelun yhteistuotannolle valuma-aluetasolla. Esimerkkialueena oli Lepsämänjoen valuma-alue Vantaanjoen vesistössä. Aineisto alueen maankäytöstä ja peltolohkojen ominaisuuksista tallennettiin paikkatietojärjestelmään. Tämä tieto yhdistettiin toimenpiteiden vaikuttavuuden kanssa optimointimallissa. Alueellisesti heterogeenisellä optimointimallilla laskettiin kustannustehokkaita ratkaisuja erilaisille monimuotoisuuden ja vesiensuojelun tasoille. Viljelijän vaihtoehtoiset pellonkäyttömuodot rajoitettiin ohranviljelyyn ja erilaisten kesantojen perustamiseen, sillä jo näilläkin maankäyttömuodoilla voidaan havainnollistaa koordinoidun vesien- ja monimuotoisuudensuojelun etuja. Lisäksi viljelijällä oli mallissa mahdollisuus vaikuttaa lannoituksen määrään ohran viljelyssä.

\section{AINEISTO JA MENETELMÄT}

Tutkimuksen kohdealueeksi valittiin Lepsämänjoen osavaluma-alue 21.042 (yhteensä 15,34 $\mathrm{km}^{2}$, josta 648 ha peltoa) Alue (Kuva 1) kuuluu pitkäaikaisen sosioekologisen maatalousekosysteemien tutkimuksen seurantaverkostoon (LTSER), ja tuloksia voidaan verrata monien muiden samalla alueella tehtyjen tutkimusten tuloksiin. Monimuotoisuutta edistävien toimenpiteiden vaikuttavuuden arvioimiseksi muodostettiin päiväperhosten ja kimalaisten monimuotoisuutta heijasteleva habitaatti-indeksi, jossa kirjallisuuden ja asiantuntija-arvioiden pohjalta valuma-alueen maatalousmaalle saatiin pellon ominaisuuksiin perustuva lukuarvo 0 ja 1 väliltä. Indeksiin vaikuttavia ympäristötekijöitä olivat rinteen kaltevuus ja kompassisuunta sekä pellon etäisyys metsän reunasta (Perhosten levinnäisyyteen vaikuttavia tekijöitä on kuvattu muissa tutkimuksissa, esimerkiksi Kuussaari ym. 2007)

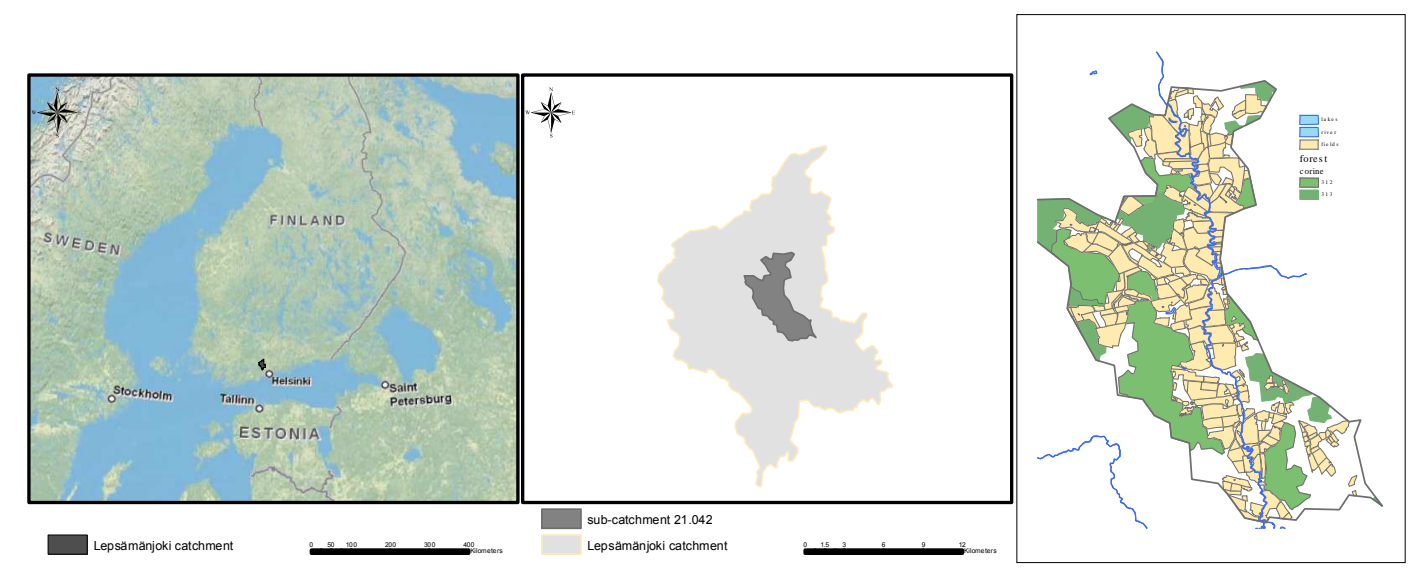

Kuva 1. Tutkimusalue. Lepsämänjoen valuma-alue ja sen osa 21.042 . 
Vesistökuormituksen alueellisiksi attribuuteiksi otettiin edellisten lisäksi maannos ja maaperän fosforiluku. Ravinnekuormituksen arvioimiseksi käytettiin Aurajoen ICECREAM-ajoista estimoituja 10 vuoden eroosio- ja valuma-arvojen keski-arvoja, huomioiden erot valuma-alueiden välisissä kaltevuus- ja maannosjakaumissa. Soveltamalla Uusitalon \& Ekholmin (2003) ja Uusitalon \& Janssonin (2002) tutkimuksia laskettiin eroosion ja valunnan perusteella leville käyttökelpoisen fosforin määrä. Typpikuormitus laskettiin suoremmin lannoitustasojen funktiona ICECREAM tuloksista. Fosfori ja typpi yhteismitallistettiin käyttämällä "Redfield: in kerrointa" eli näiden molekyylien suhdetta planktonissa.

Mallin päätösmuuttujia ovat maankäyttö (ohranviljely, tavallinen viherkesanto ja niittykasveilla perustettu kesanto) valuma-alueen eri osissa sekä lannoitusmäärät ohranviljelyssä. Kesannoinnissa vaihtoehtoisia siemenseoksia on kaksi, joista toinen vastaa tyypillistä kesantoa eli esimerksiksi ainoastaan timoitein siementä, ja toinen seos puolestaan sisältää useampaa kukkivaa niittykasvia. Niittykasviseos on kalliimpaa, mutta palvelee paremmin perhosia ja kimalaisia. Kummankin kesannon oletettiin vaikuttavan vesistökuormitukseen samoin, eli vähentävän eroosiota suhteessa ohran viljelyyn yhtä paljon. Ravinnekuormituksen vähentämisessä huomioitiin myös lannoitemäärien säätäminen. Ohran satovaste yhdistelmälannoitteelle estimoitiin typen osalta Hyytiäinen ym., (2011) tuloksista ja fosforia oletettiin käytettävän samassa suhteessa kuin Y3lannoitteessa.

Aineiston analyysissä käytettiin ArcGIS ja MS-Access ohjelmistoja. Luokittelun perusteella laskettiin valuma-alueelle sekä vesistökuormituksen että habitaatti-indeksin minimi- ja maksimiarvot. Optimoinnissa maksimoitiin viljelijän katetta ja rajoitteina käytettiin kaikkiaan 11,310 erilaista vesistökuormituksen ja habitaatti-indeksin tason yhdistelmää. Jokainen näistä optimoinneista sisälsi noin 4000 optimoitavaa muuttujaa. Epälineaarinen optimointiongelma ratkaistiin GAMS-ohjelmointia CONOPT3-algoritmia käyttäen.

\section{TULOKSET JA TULOSTEN TARKASTELU}

Kahden tuotteen tai palvelun tehokasta yhteistuotantoa kuvataan taloustieteessä usein tuotantomahdollisuuksien käyrän avulla. Kuvassa 2 esitetään tuotantomahdollisuuksien käyrät vesiensuojelulle ja monimuotoisuuden vaalimiselle kohdealueellamme. Käyrät kuvaavat suurimpia mahdollisia näiden palveluiden tasoja erilaisilla viljelijälle aiheutuvilla kustannustasoilla. Käyrät kuvaavat peltoviljelyn katetta suhteessa maksimoituun katteeseen. Vesiensuojelu (x-akseli) esitetään suhteellisena vähentymänä ravinnekuormituksessa. Habitaatin laatua kuvaava indeksi (y-akseli) esitetään myös suhteellisena katteen maksimoivan ratkaisun (indeksiarvo on 0) ja monimuotoisuutta silmälläpitäen parhaan ratkaisun (indeksiarvo 1) välillä.

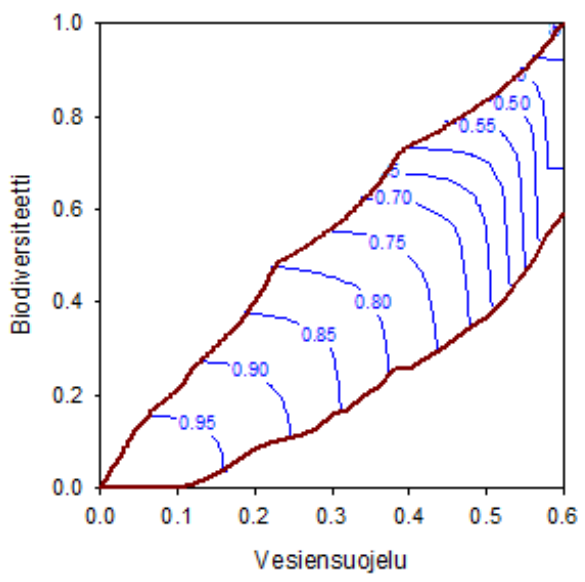

Kuva 2. Samantuotoskäyrät vesiensuojelulle ja monimuotoisuuden vaalimiselle 
Kuvan 2 tuotantomahdollisuuksien käyrä on origoon nähden konkaavi varsinkin suuremmilla tuotantotasoilla. Tämä tarkoittaa sitä, että luopumalla vähän yhden palvelun (annetuilla resursseilla maksimoidusta) tasosta voidaan kasvattaa merkittävästi toisen palvelun määrää. Yhteiskunta voi näin ollen saavuttaa kustannussäästöjä suunnittelemalla yhdessä vesien- ja monimuotoisuuden suojelun toimenpiteet ja politiikkainstrumentit. Kuvan 2 käyrät osoittavat myös, että merkittäviä ympäristöhyötyjä voidaan saavuttaa kohtuullisin kustannuksin. Esimerkiksi $10 \%$ vähennys peltoviljelyn katteessa vastaa $86 € /$ ha vuotuisia kustannuksia viljelijälle. Katteen pieneneminen voidaan tulkita myös minimikompensaatioksi, jolla rationaalinen viljelijä tuottaa näitä palveluita. Kiristyvät ympäristötavoitteet kuitenkin johtavat kasvaviin rajakustannuksiin. Merkittävä syy on maatalouden tukipolitiikassa: kesannointialan ylittäessä 50\% (tilan) pinta-alasta se lakkaa saamasta ylimenevälle osalle LFA-tukea.

(a) oh ran vilje lya la

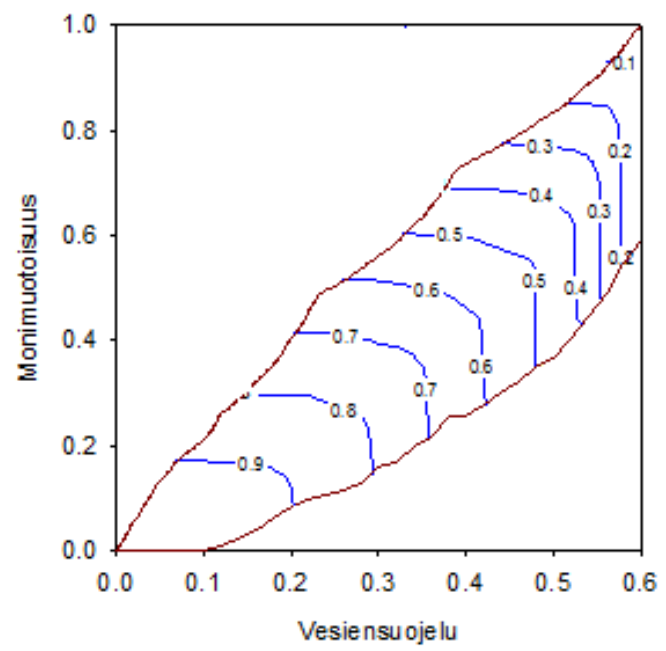

(c) n iittykasvıkesanto

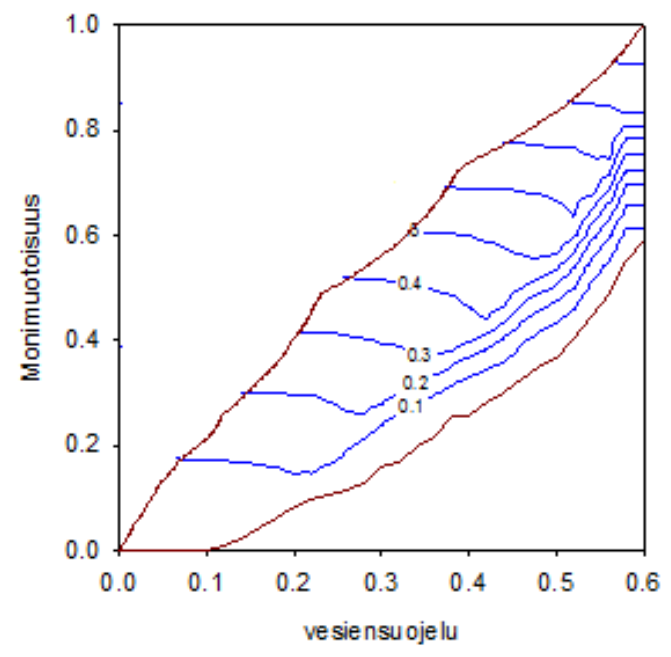

(b) tavallinen kesanto

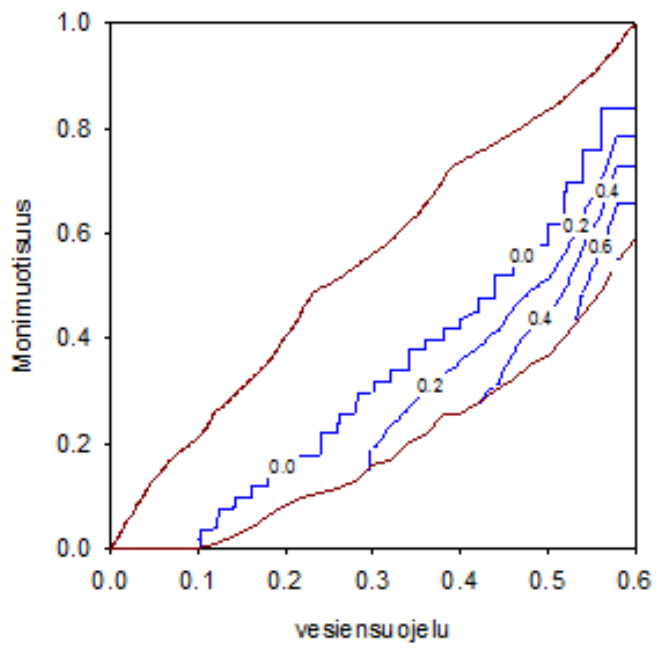

(d) typ pilanno ite $(\mathrm{kg} / \mathrm{ha})$ viljanviljelyssä

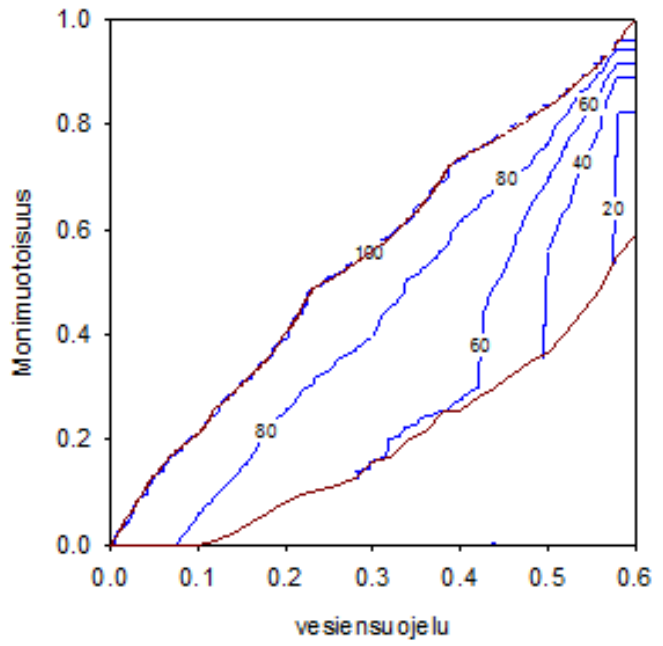

Kuva 3. Optimaalinen maankäyttö (paneelit a-c) ja typpilannoitteen määrä erilaisilla monimuotoisuuden ja vesiensuojelun tasoilla

Kuvat 3a-c esittävät viljanviljelyn ja tarkasteltavien kesantotyyppien optimaaliset osuudet alueen kokonaispeltopinta-alasta erilaisille habitaatti-indeksin ja vesiensuojelun tasoille. Kuvassa 3d on optimaalinen typpilannoitustaso vilja-alalle. Vilja-ala pienenee ympäristöhyötyjen kasvaessa (Kuva 3a). Kuten tuotantomahdollisuuksien käyrät, ovat myös maankäytön samatuottokäyrät konkaaveja. Annetuilla kustannuksilla kesantojen osuus kokonaispinta-alasta sekä alueellinen jakautuminen määräävät vesien- ja biodiversiteetin suojelun yhdistämisestä saatavat hyödyt. Mikäli 
vesiensuojelun yhteiskunnallinen painoarvo suhteessa peltobiodiversiteettiin on hyvin korkea, perinteinen viherkesanto (tai suojakaista) on tyypillinen suojelutoimenpide, kun taas vähäisempikin monimuotoisuuden painotus johtaa useita niittykasveja sisältävään kesantojen siemenseokseen. Mallissamme lannoitus ei vaikuttanut monimuotoisuuteen, joten pelkästään monimuotoisuutta edistettäessä viljan optimilannoitustaso (noin $100 \mathrm{~kg} / \mathrm{ha}$ ) pysyy samana suojelutason noustessa (Kuva $3 d)$.

Vesiensuojelutavoitteiden huomioiminen johtaa optimilannoituksen laskuun. Ensimmäinen toimenpide vesiensuojeluun ryhdyttäessä on vähentää lannoitusta 100 kilosta noin 75 kiloon typpeä per viljahehtaari. Samalla fosforilannoitus vähenee y-lannoitteen määräämässä suhteessa. Tällä muutoksella saadaan jo $10 \%$ vähennys ravinnekuormitukseen. Tätä korkeampia vähennyksiä tavoiteltaessa on tarkoituksenmukaista sekä vähentää lannoitusta että kasvattaa viherkesantopinta-alan osuutta. Ensin kesannon osuutta nostetaan kuormittavimmilla pelloilla.

Seuraavaksi tarkastelemme karttojen avulla maankäytön alueellista jakautumista valumaalueella. Ensimmäinen karttasarja (Kuva 4) näyttää vilja-alan ja kesantojen osuudet ja seuraavat kaksi sarjaa vesistökuormituksen vähennyksen (Kuva 5) ja habitaatti-indeksin (Kuva 6) kolmelle kustannustehokkaalle ratkaisulle. Ratkaisut on poimittu tuotantomahdollisuuksien käyrältä, joka edustaa n. 20\% vähennystä viljelijän katetuotossa (vrt. kuva 2). Karttasarjan ensimmäinen (vasemmanpuoleinen) kartta kuvaa tilannetta, jossa yhteiskunta painottaa vesiensuojelua. Sarjan toisessa kuvassa arvostetaan yhtä suurella painolla vesiensuojelua ja monimuotoisuutta. Kolmannessa kuvassa monimuotoisuuden suojelulla on suurempi painoarvo.

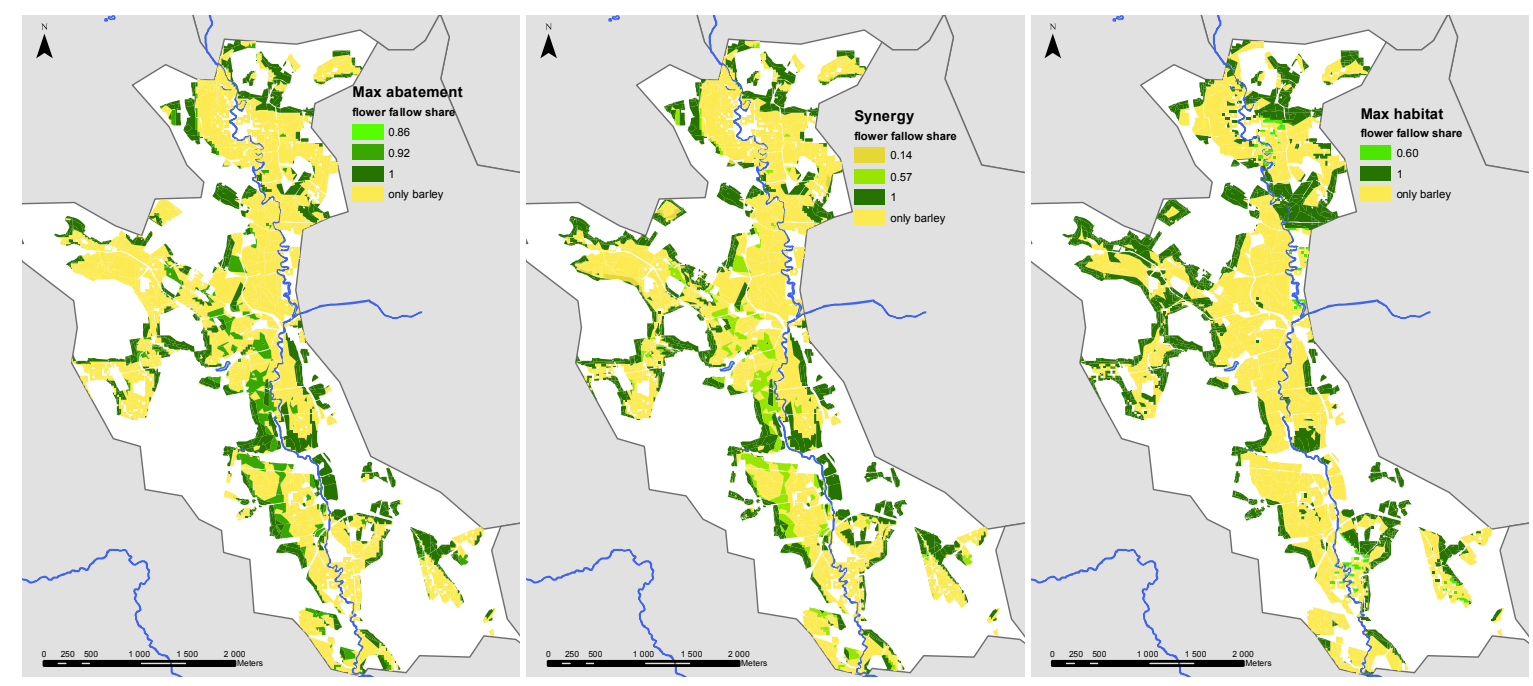

Kuva 4. Päätösmuuttujien osuudet maankäyttöluokista. Kaikissa karttapaneeleissa valuma-alueen maatalouden kate on $80 \%$ maksimitasosta. Ensimmäinen paneeli kuvaa optimiratkaisua, jossa keskitytään vesiensuojeluun. Toisessa paneelissa huomioidaan myös habitaatti-indeksi, kun taas kolmannessa keskitytään ainoastaan siihen. Kaikissa paneeleissa niittykukkaseos korvaa tavallisen kesannon siemenseoksen. Tämän biodiversiteetille edullisemman kesantotyypin osuutta kuvataan vihreällä värillä. Alueet, joiden viljelykiertoon ei tulisi lainkaan kesantoa on kuvattu keltaisella värillä. Tummin vihreistä sävyistä puolestaan kuvaa alan jättämistä ainoastaan kesannolle.

Kuva 5 havainnollistaa miten ravinnekuormituksen vähennys jakautuu valuma-alueen sisällä. Maksimaalinen kokonaisvähennys on $36 \%$, kun taas monimuotoisuuteen keskityttäessä saavutetaan $20 \%$ vähenemä kuormituksessa. Synergistisen ratkaisun kokonaisvähennys on $34 \%$ ja kuvasta 5 nähdäänkin että suuremmat vähennykset per hehtaari kohdentuvat samoille aluille. Monimuotoisuuden edistämiseen keskittyvässä ratkaisussa saadaan myös paikallisesti merkittäviä vähentymiä, sillä jyrkempien rinteiden kesannoiminen johtaa kuormituksen vähenemiseen silloinkin kun päätavoitteena on ollut auringonpaisteisen niityn luominen päiväperhosille ja kimalaisille. 


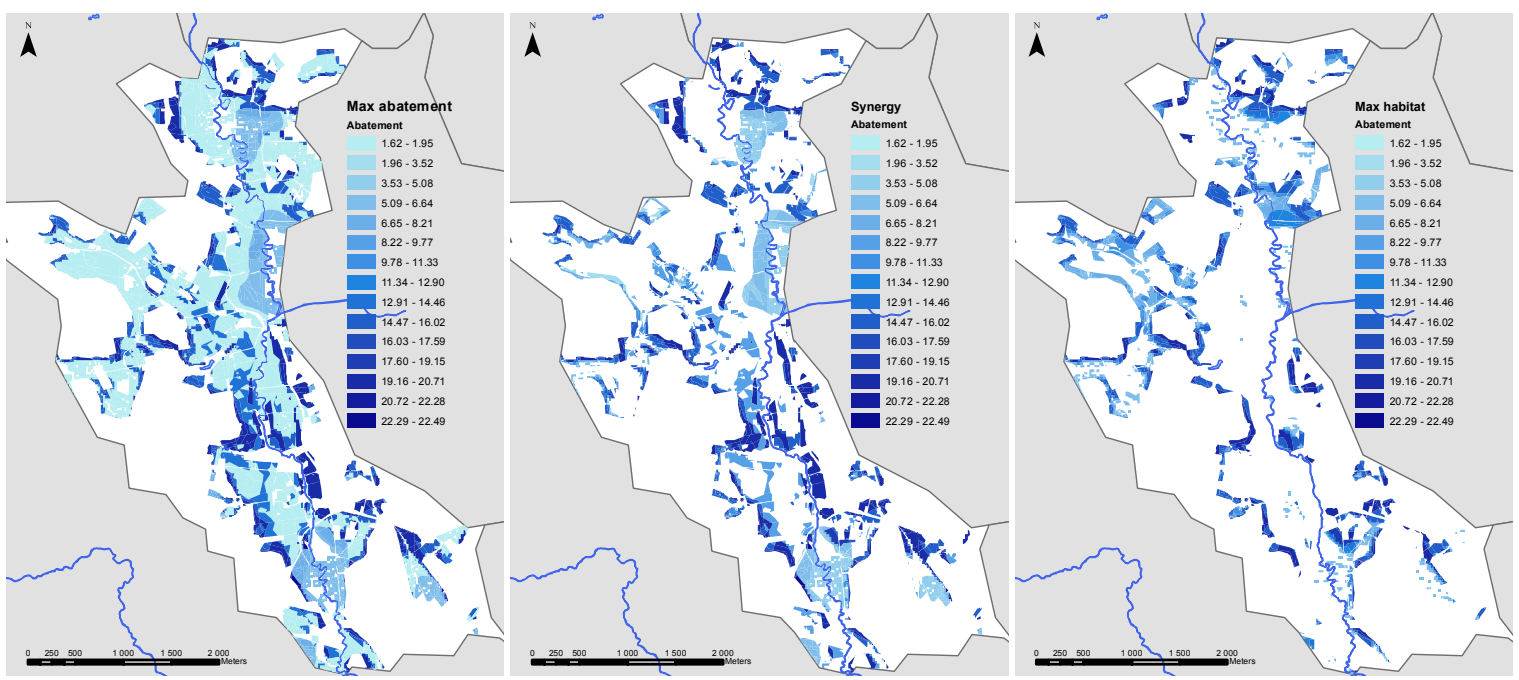

Kuva 5. Optimiratkaisujen alueellinen jakauma kuormituksen vähennyksille. Näillä kustannuksilla alueen kokonaisravinnekuormitusta voidaan vähentää enintään 36\%. Sinisen tummempi sävy kuvaa peltoja, joiden osuus kuormituksen vähennyksestä on suuri. Suurimmallaan yhteiskuormituksen vähennys on 22.5 kiloa hehtaarille. Vaaleilla alueilla vähennys on pienempi.

Kuva 6 näyttää habitaatti-indeksin muutokset eri yhteiskunnallisille ympäristöhyödykkeiden painotuksille. Samoin kuin kuvassa 5 esitetyssä kesanto-osuudessa, on kuvan 6 habitaatti-indeksissä mielenkiintoista kuinka vesiensuojelutavoitteita painotettaessakin on päädytty käyttämään niittykukkaseosta. Tällainen kesanto on tavanomaista kesantoa kalliimpaa, mutta se tarjoaa paremmat puitteet päiväperhosille ja kimalaisille. Siirtyminen normaalista viherkesannosta niittykasviseoksella kylvettyyn kesantoon on halvempaa kuin viherkesanto-osuuden lisääminen ohran kustannuksella.

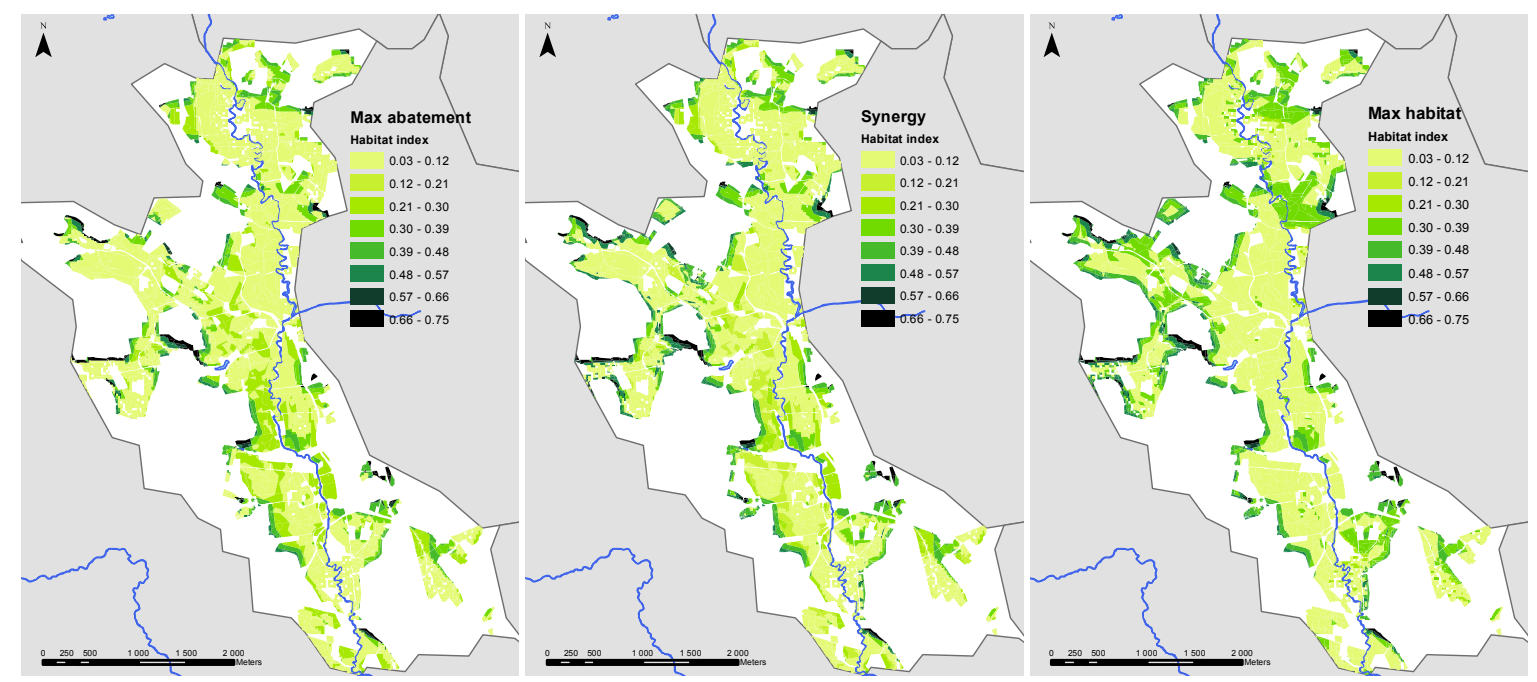

Kuva 6. Habitaatti-indeksi erilaisille yhteiskunnallisille painotuksille.

Painotettaessa habitaatin merkitystä ilman vesiensuojelullisia tavoitteita, kasvaa nittykasvikesannon osuus niilläkin metsänreunamilla, jotka eivät ole kaltevia tai maalajiltaan eroosioherkkiä. 


\section{JOHTOPÄ̈̈TÖKSET}

Tulostemme mukaan koordinoitu vesien- ja monimuotoisuuden suojelun suunnittelu tuottaa kustannussäästöjä verrattaessa tilanteeseen, jossa toimenpiteet suunnitellaan toisistaan riippumatta. Kustannussäästöjen suuruus on kuitenkin ehdollinen valuma-alueen ominaisuuksille, vaihtoehtoisten toimenpiteiden määrille ja niiden vaikuttavuudelle ja myös sille missä suhteessa yhteiskunta arvostaa vesien- ja monimuotoisuuden suojelua. Vesiensuojelun kannalta tärkeä jyrkempien rinteiden kasvipeitteisyys korostuu entisestään kun huomioidaan tavoitteet myös maatalousympäristön monimuotoisuudelle. Tuloksiamme tulkittaessa on otettava huomioon mallistamme puuttuvat ominaisuudet ja vuorovaikutukset. Oletamme esimerkiksi, että kesantojen vaikutus perhosten ja kimalaisten habitaattiin kasvaa lineaarisesti kesantojen pinta-alan suhteen. Joidenkin lajiryhmien osalta monimuotoisuustoimenpiteen tehokkuuteen vaikuttavat myös kesannoitavien alueiden muoto ja se miten alueet liittyvät toisiinsa (vrt. esim. ekologiset käytävät). Ravinnekuormituksen osalta esimerksi valuma-alueen peltojen fosforipitoisuuden vaihtelua ei kyetty huomioimaan käytettävissä olleella aineistolla, vaikka kehittämämme malli siihen kykeneekin. Mallikehikkomme oletukset ovat muutettavissa ja laskelmat toistettavissa, kun erilaisten toimenpiteiden vaikuttavuudesta ja kustannuksista saadaan uutta tietoa. Samoin laskelmat ovat toistettavissa muille valuma-alueille.

\section{KIRJALLISUUS}

Hyytiäinen, K.., Niemi, J. K., Koikkalainen, K., Palosuo, T. \& Salo, T. 2011. Adaptive optimization of crop production and nitrogen leaching abatement under yield uncertainty Agricultural Systems, 104, 634 - 644 Kuussaari M., Heliölä, J. Pöyry, J. \& Saarinen, K. 2007. Contrasting trends of butterfly species preferring semi-natural grasslands, field margins and forest edges in northern Europe. Journal of Insect Conservation 11, 351-366

Uusitalo, R. \& Ekholm, P. 2003. Phosphorus in runoff assessed by anion exchange resin extraction and an algal assay. Journal of Environmental Quality, 32, 633-641

Uusitalo, R. \& Jansson, H. 2002. Dissolved reactive phosphorus in runoff assessed by soil extraction with an acetate buffer. Agricultural and Food Science in Finland, 11, 343-353 